Pak. j. sci. ind. res. Ser. B: biol. sci. 2017 60(1) 19-26

\title{
Barley and Oat Meal Supplemented Chapaties and its Impact on Serum Biochemical Profile in Normal Individuals
}

\author{
Rebia Ejaz*, Mian Kamran Sharif, Imran Pasha, Sabiha Abbas, \\ Abdul Wadood and Ayesha Amin \\ National Institute of Food Science and Technology, Faculty of Food, Nutrition and Home Sciences, \\ Faisalabad-38040, Pakistan
}

(received August 4, 2015; revised June 13, 2016; accepted June 19, 2016)

\begin{abstract}
The present study was taken to prepare barley and oat meal supplemented flours with special reference to chapati making quality. For this purpose, nine treatments of supplemented flours were prepared by gradually replacing whole wheat. Chapaties were prepared from all compositions along with control ( $100 \%$ whole wheat flour) and analysed for dietary fibre content and sensory attributes like colour, taste, aroma, texture, breakability, folding ability, chewability and overall acceptability at stated intervals. Efficacy study was carried out on healthy individuals to explore the hypocholesterolemic and hypoglycemic worth of chapaties prepared from supplemented flours. Results of dietary fibre analysis showed that there was significant increase in level of soluble 0.96 to $3.13 \%$, insoluble 1.92 to $5.57 \%$ and total dietary fibre content 2.88 to $8.13 \%$ with increase in the supplementation level of barley and oat meal. The highest soluble (3.13), insoluble (5.57) and total dietary fibre (8.13) content were found in wheat flour supplemented with 7.5\% oat meal and $7.5 \%$ barley flour while their concentration was not changed during storage. Sensory attributes showed that chapaties prepared from wheat flour supplemented with $7.5 \%$ oat meal and $7.5 \%$ barley flour were liked the most due to better overall acceptability. On the basis of nutritional and sensory characteristics, three best chapaties along with control were served to normal humans. The results revealed that consumption of chapaties supplemented with $15 \%$ oat meal greatly reduced serum cholesterol $(7.7 \%)$, low density lipoprotein (6.8\%), triglycerides (28.5\%), blood glucose $(5.5 \%)$ and weight $(4.7 \%)$ while increased high density lipoprotein $(2.0 \%)$, serum protein (12.5\%) and albumin protein (15.7\%) as compared to other two chapaties. It is concluded that the consumption of barley and oat meal supplemented chapaties tackle the hyperglycemia and hypercholesterolemia in healthy humans as well as in obese persons because it deliver three times more dietary fibre as compared to chapaties prepared from wheat flour only.
\end{abstract}

Keywords: barley, oat meal, $\beta$-glucan, chapaties, hyperglycemia

\section{Introduction}

The consumption of healthy food products such as sugar-free, low caloric and high fibre products is increasing in modern era to overcome health complications. Cereal grains provide protein, dietary fibre, energy, antioxidants and vitamins required for human health. Cereal grain is mainly comprised of endosperm, germ and bran portion. However, after milling of these grains many of the nutrients present in the bran and germ portion are lost leaving behind carbohydrates only. Cereal grains including wheat, sorghum, barley, rice and corn contribute a huge share (68\%) in the world food supplies. Consumption of fruits, vegetables and whole grains increase the energy and nutritional profile of humans. The high fibre whole grain cereals contain low sugar contents which makes the foods more nutritive. The nutritionists suggest that consumption of cereal foods daily is better for health instead of rely on just one food (Anjum et al., 2005; Slavin, 2004).

*Author for correspondence; E-mail: rebiaejaz.2500@gmail.com
Wheat (Triticum aestivum L.), barley (Hordeum vulgare L.) and oat (Avena sativa L.) are important cereal food crops. Wheat a major dietary staple supplies instant energy and proteins to the world population as contrast to other cereal crops. The health benefit of whole grain products are mainly due to the occurrence of bioactive compounds. Multifunctional and nutritional profile of oat and barley is unique among cereals (Butt et al., 2011; Sramkova et al., 2009; Thondre and Henry, 2009). Barley and oat meal are rich sources of soluble dietary fibre which provide protection against many health ailments like gastrointestinal diseases, colon cancer, diabetes, overweight and obesity. These cereals can be supplemented with whole wheat flour to form a wide range of healthful baked foodstuff.

Dietary fibres are very complex carbohydrates and lignins that are not broken down in the upper gut due to absence of intestinal enzymes. Dietary fibre $\beta$-glucan content imparts potential beneficial effects when used as part of the human diet. The number of people suffering 
from elevated blood glucose and cholesterol, especially low density lipoprotein is increasing briskly in Pakistan. To overcome the menace, little efforts have been flinching towards diet diversification, modification and improvement in the nutritional value of commonly used foods.

The US Food and Drug Administration endorsed daily intake of $3 \mathrm{~g}$ dietary fibre which contains $0.75 \mathrm{~g}$ of $\beta$-glucan of barley to abate the development of heart diseases and other metabolic disorders. About 85-90\% of wheat produced in world is used in the form of unleavened flat bread locally known as chapati mostly prepared from the whole wheat flour. Typically, it is consumed hot along with other sauces, gravies and chutneys (Hemalatha et al., 2010; Akhtar et al., 2008).

The present study was designed to augment the consumption of dietary fibre in Pakistan by supplementing innumerable levels of underutilised dietary fibre rich sources. The main objectives of the study were to develop barley and oat meal supplemented flours with special reference to chapati making quality and compute the acceptability of chapaties through chemical analysis and sensory evaluation. Another notable point of study was to explore the influence of chapaties prepared from supplemented flours on serum biochemical profile in normal human beings.

\section{Materials and Methods}

Preparation of chapaties. Commercially available varieties of barley (Haider) and wheat variety (Galaxy, 2013) were procured in the year 2014 from Ayub Agricultural Research Institute, Faisalabad, Pakistan. Oat grains were acquired from Pakistan Agricultural Research Center (PARC), Islamabad, Pakistan. Barley and oat meal flour were supplemented in whole wheat flour by gradually replacing wheat flour to prepare composite flours (Table 1) and stored in polyethylene zip bags at room temp $\left(25^{\circ} \mathrm{C} \pm 5\right)$ for 45 days. Additionally, chapaties were prepared from all compositions following the method of Haridas et al. (1986) with slight amendments. Dough was prepared by mixing $200 \mathrm{~g}$ flour with $135 \mathrm{~mL}$ water in mixer and covered to give rest time. Then it was divided into balls followed by molding into a smooth disc on a flour dusted wooden board using a rolling pin to get chapaties with uniform diameter and thickness. The uncooked chapaties were quickly transferred to a pre heated hot plate at $240{ }^{\circ} \mathrm{C}$. After $30 \mathrm{sec}$ the chapati was turned and pressed with the soft cloth to spread the steam uniformly. Chapaties were cooled and packed in individual polyethylene bags for further analysis.

Total dietary fibre analysis. The chapaties were analysed for total dietary fibre, soluble and insoluble dietary fibre content according to method No. 32-05, 32-07 and 32-20, respectively as described in AACC by employing Megazyme Assay Kit (AACC, 2000). The samples were dispersed in a buffer solution and incubated with heat-stable $\alpha$-amylase at $95-100{ }^{\circ} \mathrm{C}$ for $35 \mathrm{~min}$. After cooling the samples were conceived at $60{ }^{\circ} \mathrm{C}$ for $30 \mathrm{~min}$ by adding $100 \mu \mathrm{L}$ protease solution. Furthermore, $\alpha$-amylase and protease treated samples were incubated with amyloglucosidase at $60{ }^{\circ} \mathrm{C}$ for $30 \mathrm{~min}$. The fibre contents were precipitated by the addition of alcohol in 1:4 ratios and filtered to eliminate other substances. The remnant was washed with alcohol and acetone. A blank was run in a similar manner.

Sensory evaluation. Sensory evaluation of barley and oat meal supplemented chapaties was performed for various attributes like colour, texture, folding ability, chewability, taste and overall acceptability by a penal

Table 1. Treatments used in study for barley and oat meal supplemented flours

\begin{tabular}{llll}
\hline \hline Treatments & Wheat flour & Oat meal & Barley flour \\
\cline { 2 - 4 } & \multicolumn{3}{c}{$(\%)$} \\
WF & 100 & - & - \\
WF-OF-5 & 95 & 5 & - \\
WF-OF-10 & 90 & 10 & - \\
WF-OF-15 & 85 & 15 & - \\
WF-BF-5 & 95 & - & 5 \\
WF-BF-10 & 90 & - & 10 \\
WF-BF-15 & 85 & - & 15 \\
WF-OBF-2.5 & 95 & 2.5 & 2.5 \\
WF-OBF-5 & 90 & 5 & 5 \\
WF-OBF-7.5 & 85 & 7.5 & 7.5 \\
\hline \hline
\end{tabular}

$\mathrm{WF}=100 \%$ whole wheat flour; WF-OF-5 $=$ wheat flour supplemented with $5 \%$ oat meal; WF-OF-10 $=$ wheat flour supplemented with $10 \%$ oat meal; WF-OF-15 = wheat flour supplemented with $15 \%$ oat meal; WF-BF-5 = wheat flour supplemented with $5 \%$ barley flour; WF-BF-10 $=$ wheat flour supplemented with $10 \%$ barley flour; WF-BF-15 = wheat flour supplemented with $15 \%$ barley flour; WF-OBF-2.5 = wheat flour supplemented with $2.5 \%$ oat meal and $2.5 \%$ barley flour; WF-OBF-5 = wheat flour supplemented with $5 \%$ oat meal and 5\% barley flour; WF-OBF-7.5 = wheat flour supplemented with $7.5 \%$ oat meal and $7.5 \%$ barley flour. 
of 8 judges. They used 9-point Hedonic score system to evaluate the chapaties following the procedure of Meilgaard et al. (2007).

Efficacy studies. On the basis of chemical assay and sensory attributes three chapaties comprising of (i) $15 \%$ oat meal, (ii) $15 \%$ barley flour and (iii) $7.5 \%$ oat meal and $7.5 \%$ barley flour showing suitability for product development along with control were selected for efficacy purposes. Efficacy trail was conducted on healthy individuals to determine the impact of selected chapaties on serum biochemical profile including serum cholesterol, high density lipoprotein, low density lipoprotein, triglycerides, glucose, total protein and albumin concentration during 30 days study interval. For this purpose, 18 healthy persons (male and female) of age period 25-40 years were randomly divided into three groups having six in each and were feed on two chapaties per day. Body weight of the subjects were measured fortnightly throughout the experimental period. Blood samples were collected at the baseline, mid and end of the study.

Statistical analysis. The data obtained from all parameters were subjected to the analysis of variance and two way factorial design using statistical package Statisix 8.1 (Steel et al., 1997). The calculated mean values were compared using Turkey test with significance defined at $\mathrm{p}>0.05$.

\section{Results and Discussion}

Dietary fibre analysis. The mean values for soluble, insoluble and total dietary fibre content of whole wheat flour supplemented with barley and oat meal revealed highly significant effect of different flour compositions and storage intervals. Wheat flour was supplemented with $7.5 \%$ oat meal and $7.5 \%$ barley flour having total dietary fibre $(8.13 \%)$ comprising of soluble $(3.13 \%)$ and insoluble (5.57) fibre. Results of analysis showed that there was significant increase in soluble fibre $(0.96$ to $3.13 \%$ ), insoluble fibre (1.92 to $5.57 \%$ ) and total dietary fibre content (2.88 to $8.13 \%$ ) with increase in the supplementation level (Table 2). Soluble dietary fibre content was $2.78 \%$ at 0 day which was gradually decreased to $2.76,2.73$ and $2.70 \%$ at 15,30 and 45 days, respectively during the storage.

At the beginning of the study, the insoluble and total dietary fibre content were $4.68 \%$ and $7.36 \%$ which was gradually increased to $4.71,4.74$ and $4.76 \%$ in insoluble fibre and $7.36,7.38$ and $8.13 \%$ in total dietary fibre
Table 2. Mean values of dietary fibre content of barley and oat meal supplemented chapaties

\begin{tabular}{llll}
\hline \hline Treatments & T D F & S D F & I D F \\
\hline WF & $6.04 \pm 0.01^{\mathrm{j}}$ & $0.96 \pm 0.09^{\mathrm{j}}$ & $1.92 \pm 0.04^{\mathrm{j}}$ \\
WF-OF-5 & $7.51 \pm 0.05^{\mathrm{i}}$ & $2.65 \pm 0.05^{\mathrm{i}}$ & $4.56 \pm 0.02^{\mathrm{i}}$ \\
WF-OF-10 & $7.60 \pm 0.08^{\mathrm{h}}$ & $2.73 \pm 0.05^{\mathrm{h}}$ & $4.65 \pm 0.03^{\mathrm{h}}$ \\
WF-OF-15 & $7.72 \pm 0.08^{\mathrm{g}}$ & $2.78 \pm 0.04^{\mathrm{g}}$ & $4.79 \pm 0.05^{\mathrm{g}}$ \\
WF-BF-5 & $7.83 \pm 0.06^{\mathrm{f}}$ & $2.92 \pm 0.04^{\mathrm{f}}$ & $4.90 \pm 0.03^{\mathrm{f}}$ \\
WF-BF-10 & $7.92 \pm 0.06^{\mathrm{e}}$ & $3.00 \pm 0.04^{\mathrm{e}}$ & $5.00 \pm 0.04^{\mathrm{e}}$ \\
WF-BF-15 & $8.01 \pm 0.04^{\mathrm{d}}$ & $3.06 \pm 0.05^{\mathrm{d}}$ & $5.09 \pm 0.11^{\mathrm{d}}$ \\
WF-OBF-2.5 & $8.04 \pm 0.03^{\mathrm{c}}$ & $3.10 \pm 0.02^{\mathrm{c}}$ & $5.30 \pm 0.09^{\mathrm{c}}$ \\
WF-OBF-5 & $8.06 \pm 0.13^{\mathrm{b}}$ & $3.11 \pm 0.06^{\mathrm{b}}$ & $5.46 \pm 0.07^{\mathrm{b}}$ \\
WF-OBF-7.5 & $8.24 \pm 0.05^{\mathrm{a}}$ & $3.13 \pm 0.07^{\mathrm{a}}$ & $5.57 \pm 0.70^{\mathrm{a}}$ \\
\hline
\end{tabular}

$\mathrm{TDF}=$ total dietary fibre; $\mathrm{SDF}=$ soluble dietary fibre; IDF $=$ insoluble dietary fibre; values are Mean \pm SD for samples analysed individually in triplicate; superscripts indicate the implementation of statistical technique (Tukey's Test).

Table 3. Effect of storage on dietary fiber content of barley and oat meal supplemented chapaties

\begin{tabular}{llll}
\hline \hline Storage & T D F & S D F & I D F \\
\hline $\mathrm{S}_{0}$ & $7.35 \pm 3.66$ & $2.78 \pm 1.52$ & $4.68 \pm 2.57$ \\
$\mathrm{~S}_{15}$ & $7.36 \pm 3.70$ & $2.76 \pm 1.54$ & $4.71 \pm 2.57$ \\
$\mathrm{~S}_{30}$ & $7.38 \pm 3.73$ & $2.73 \pm 1.52$ & $4.74 \pm 2.58$ \\
$\mathrm{~S}_{45}$ & $7.38 \pm 3.73$ & $2.70 \pm 1.54$ & $4.76 \pm 2.60$ \\
\hline \hline
\end{tabular}

$\mathrm{TDF}=$ total dietary fibre; SDF $=$ soluble dietary fibre; IDF $=$ insoluble dietary fibre; values are Mean \pm SD for samples analysed individually in triplicate; superscripts indicate the implementation of statistical technique (Tukey's Test); $\mathrm{S}_{0}=$ storage at 0 day; $\mathrm{S}_{15}=$ storage at 15 days; $\mathrm{S}_{30}=$ storage at 30 days, $\mathrm{S}_{45}=$ storage at 45 days; values are mean $\pm \mathrm{SD}$ for samples analysed individually in triplicate.

content, respectively as the study continued (Table 3 ). Total dietary fibre content of oat and barley especially $\beta$-glucan ranged from 6.5 to $8.5 \%$ correspondingly (Sudha et al., 2007). There was a progressive increase in dietary fibre with the addition of barley and oat meal which control glucose and cholesterol level in the body. It is suggested from the present study that consumption of chapaties prepared from composite flours containing barley and oat meal provide an additional dietary fibre that would be helpful for the diabetic and obese patients.

Sensory evaluation. The mean squares of colour, texture, folding ability, chewiness, taste and overall acceptability revealed significant differences among all composition and storage intervals. The maximum score of 9 for the 
above mentioned attributes was found in chapaties prepared from wheat flour supplemented with 7.5\% oat meal and $7.5 \%$ barley flour. The second highest score of 8.4 was awarded to chapaties prepared by wheat flour supplemented with $15 \%$ barley flour due to its attractive and appealing light brown colour, soft texture, chewable nature and pleasant taste. The lowest score of 4.5 and least overall acceptability was given to chapaties prepared from wheat flour supplemented with $15 \%$ oat meal. The second minimum score of 5.0 was assigned to chapaties prepared from $10 \%$ oat meal (Table 4). Whole wheat flour chapaties was scored 7 due to its good colour, taste and soft texture. From the mean values for storage, it was observed that colour, texture, folding ability, chewiness, taste and overall acceptability of chapaties decreased during storage.

The mean values of colour of chapaties at $0,15,30$ and 45 days interval were 7.22, 7.20, 6.68 and 6.66 and of texture of chapaties were at $0,15,30$ and 45 day interval were $6.9,6.8,6.7$ and 6.6. The mean values of folding ability at $0,15,30$ and 45 day interval were $5.97,5.95$,
5.93 and 5.88 and of chewability at $0,15,30$ and 45 day interval were $6.4,6.32,6.3$ and 6.29 , while the mean values of taste of chapaties at $0,15,30$ and 45 day interval were $6.78,6.74,6.71$ and 6.6. The mean values of overall acceptability at $0,15,30$ and 45 day interval were $6.78,6.74,6.71$ and 6.6 (Table 5). The migration and absorption of moisture, oxidation of fat and increased mold count result in loss of colour and palatability in chapaties during storage (Butt et al., 2007; Sharif et al., 2005).

The decrease in quality score for texture was due to absorption of moisture that has negative impact on texture. The dwindling trend in folding ability, chewiness and taste of chapaties was certainly due to dryness. Escalation in moisture has an inverse correlation with the chewiness. Lowest acceptability of oat meal chapaties was due to little change in taste and texture. Similarly, declining trend in scores for overall acceptability was observed in oat meal chapaties during various storage intervals that might be due to the development of rancidity, protein and lipid breakdown and mold infestation (Sharma et al., 2012; Wade, 1998).

Table 4. Mean values of sensory evaluation of barley and oat meal supplemented chapaties

\begin{tabular}{|c|c|c|c|c|c|c|}
\hline Treatments & Colour & Texture & Folding ability & Chewability & Taste & Overall acceptability \\
\hline WF & $7.40 \pm 0.09^{\mathrm{e}}$ & $7.40 \pm 0.09^{\mathrm{e}}$ & $5.9 \pm 0.09^{\mathrm{e}}$ & $6.5 \pm 0.04^{\mathrm{e}}$ & $6.90 \pm 0.06^{\mathrm{e}}$ & $7.00 \pm 0.06^{\mathrm{e}}$ \\
\hline WF-OF-5 & $5.90 \pm 0.09^{\mathrm{h}}$ & $5.90 \pm 0.09^{\mathrm{h}}$ & $4.9 \pm 0.11^{\mathrm{h}}$ & $6.2 \pm 0.34^{\mathrm{h}}$ & $5.50 \pm 0.06^{\mathrm{h}}$ & $5.50 \pm 0.06^{\mathrm{h}}$ \\
\hline WF-OF-10 & $5.40 \pm 0.09^{\mathrm{i}}$ & $5.40 \pm 0.09^{\mathrm{i}}$ & $4.5 \pm 0.08^{\mathrm{i}}$ & $4.5 \pm 0.07^{\mathrm{i}}$ & $5.00 \pm 0.43^{\mathrm{i}}$ & $5.00 \pm 0.43^{\mathrm{i}}$ \\
\hline WF-OF-15 & $4.90 \pm 0.09^{j}$ & $4.90 \pm 0.09^{\mathrm{j}}$ & $4.4 \pm 0.19^{j}$ & $3.9 \pm 0.51^{\mathrm{j}}$ & $4.50 \pm 0.08^{j}$ & $4.50 \pm 0.08^{\mathrm{j}}$ \\
\hline WF-BF-5 & $7.90 \pm 0.09^{\mathrm{d}}$ & $7.90 \pm 0.09^{\mathrm{d}}$ & $5.45 \pm 0.09^{\mathrm{d}}$ & $7.4 \pm 0.33^{\mathrm{d}}$ & $7.50 \pm 0.10^{\mathrm{d}}$ & $7.50 \pm 0.10^{\mathrm{d}}$ \\
\hline WF-BF-10 & $8.40 \pm 0.07^{\mathrm{c}}$ & $8.40 \pm 0.07^{\mathrm{c}}$ & $7.0 \pm 0.09^{\mathrm{c}}$ & $7.5 \pm 0.12^{\mathrm{c}}$ & $7.90 \pm 0.24^{\mathrm{c}}$ & $7.90 \pm 0.24^{\mathrm{c}}$ \\
\hline WF-BF-15 & $8.70 \pm 0.10^{b}$ & $8.60 \pm 0.10^{b}$ & $7.5 \pm 0.07^{\mathrm{b}}$ & $8.15 \pm 0.09^{b}$ & $8.40 \pm 0.09^{b}$ & $8.40 \pm 0.09^{b}$ \\
\hline WF-OBF-2.5 & $6.90 \pm 0.09^{\mathrm{f}}$ & $6.90 \pm 0.09^{\mathrm{f}}$ & $6.5 \pm 0.07^{\mathrm{d}}$ & $5.25 \pm 0.09^{\mathrm{g}}$ & $6.10 \pm 0.36^{\mathrm{g}}$ & $6.20 \pm 0.36^{\mathrm{g}}$ \\
\hline WF-OBF-5 & $6.50 \pm 0.09^{\mathrm{g}}$ & $6.50 \pm 0.09^{\mathrm{g}}$ & $5.4 \pm 0.09^{\mathrm{f}}$ & $5.5 \pm 0.09^{\mathrm{f}}$ & $6.60 \pm 0.07^{\mathrm{f}}$ & $6.50 \pm 0.07^{\mathrm{f}}$ \\
\hline WF-OBF-7.5 & $8.80 \pm 0.09^{\mathrm{a}}$ & $8.70 \pm 0.09^{\mathrm{a}}$ & $8.0 \pm 0.09^{\mathrm{a}}$ & $8.5 \pm 0.07^{\mathrm{a}}$ & $8.75 \pm 0.09^{\mathrm{a}}$ & $8.80 \pm 0.09^{\mathrm{a}}$ \\
\hline
\end{tabular}

Values are mean $\pm \mathrm{SD}$ for samples analysed individually in triplicate; Means within a row with different letters are significantly different $(\mathrm{p}<0.05)$; superscripts indicate the implementation of statistical technique (Tukey's Test).

Table 5. Effect of storage on sensory evaluation of barley and oat meal supplemented chapaties

\begin{tabular}{lllllll}
\hline \hline Storage & Colour & Texture & Folding ability & Chew ability & Taste & Overall acceptability \\
\hline $\mathrm{S}_{0}$ & $7.22 \pm 1.41$ & $6.9 \pm 1.41$ & $5.97 \pm 1.42$ & $6.40 \pm 1.41$ & $6.78 \pm 1.40$ & $6.78 \pm 1.40 \mathrm{a}$ \\
$\mathrm{S}_{15}$ & $7.20 \pm 1.41$ & $6.8 \pm 1.41$ & $5.95 \pm 1.40$ & $6.32 \pm 1.41$ & $6.74 \pm 1.37$ & $6.74 \pm 1.37 \mathrm{ab}$ \\
$\mathrm{S}_{30}$ & $6.68 \pm 1.39$ & $6.7 \pm 1.39$ & $5.93 \pm 1.39$ & $6.30 \pm 1.39$ & $6.71 \pm 1.37$ & $6.71 \pm 1.37 \mathrm{c}$ \\
$\mathrm{S}_{45}$ & $6.66 \pm 1.41$ & $6.6 \pm 1.41$ & $5.88 \pm 1.41$ & $6.29 \pm 1.39$ & $6.66 \pm 1.37$ & $6.60 \pm 1.37 \mathrm{~d}$ \\
\hline
\end{tabular}

$\overline{\mathrm{S}_{0}}=$ storage at 0 day; $\mathrm{S}_{15}=$ storage at 15 days; $\mathrm{S}_{30}=$ storage at 30 days, $\mathrm{S}_{45}=$ storage at 45 days; values are mean $\pm \mathrm{SD}$ for samples analysed individually in triplicate. 
Efficacy results. Mean values for serum biochemical profile of normal individuals consuming dietary fibre enriched chapaties exhibited significant effect of different flour compositions and efficacy trial intervals. The maximum cholesterol concentration $(189 \mathrm{mg} / \mathrm{dL})$ was found in normal individuals fed on chapaties containing wheat flour only followed by 174 and $155 \mathrm{mg} / \mathrm{dL}$ in groups fed on chapaties supplemented with $15 \%$ barley and $15 \%$ oat meal, respectively. The maximum high density lipoprotein concentration $(46.1 \mathrm{mg} / \mathrm{dL})$ was found in normal individuals fed on chapaties containing wheat flour only followed by 44.4 and $43 \mathrm{mg} / \mathrm{dL}$ in groups fed on chapaties supplemented with $15 \%$ barley (WF-BF-15) and $15 \%$ oat meals and maximum low density lipoprotein concentration $(101 \mathrm{mg} / \mathrm{dL})$ was found in normal individuals fed on chapaties containing wheat flour followed by 99.8 and $77.7 \mathrm{mg} / \mathrm{dL}$ in groups fed on chapaties supplemented with $15 \%$ barley and $15 \%$ oat meal, respectively.

The maximum triglycerides concentration $(141 \mathrm{mg} / \mathrm{dL})$ was found in normal individuals fed on chapaties containing wheat flour followed by 130 and $114 \mathrm{mg} / \mathrm{dL}$ in groups fed on chapaties supplemented with $15 \%$ barley and $15 \%$ oat meal and maximum glucose concentration $(90 \mathrm{mg} / \mathrm{dL})$ was found in normal individuals fed on chapaties containing wheat flour only followed by 87 and $84 \mathrm{mg} / \mathrm{dL}$ in groups fed on chapaties supplemented with $15 \%$ barley and $15 \%$ oat meal, respectively. The minimum serum protein concentration $(6.7 \mathrm{~g} / \mathrm{dL})$ was found in normal individuals fed on chapaties containing wheat flour followed by 6.8 and $6.9 \mathrm{~g} / \mathrm{dL}$ in groups fed on chapaties supplemented with $15 \%$ barley and $15 \%$ oat meal and albumin protein concentration $(4.5 \mathrm{~g} / \mathrm{dL})$ was found in normal individuals fed on chapaties containing wheat flour only followed by 4 and $3.8 \mathrm{mg} / \mathrm{dL}$ in groups fed on chapaties supplemented with $15 \%$ barley and $15 \%$ oat meal, respectively. It was revealed that maximum weight $(70 \mathrm{~kg})$ was found in normal individuals fed on chapaties containing wheat flour followed by 67 and $64 \mathrm{~kg}$ in groups fed on chapaties supplemented with $15 \%$ barley and $15 \%$ oat meal, respectively.

At the initiation of the study, mean values of cholesterol was $179.3 \mathrm{mg} / \mathrm{dL}$ which gradually decreased to 174.1 and $164.3 \mathrm{mg} / \mathrm{dL}$. At the 0 day of the study, mean values of high density lipoprotein were $45.3 \mathrm{mg} / \mathrm{dL}$ which gradually decreased to 45 and $44.5 \mathrm{mg} / \mathrm{dL}$, values of low density lipoprotein was $98.1 \mathrm{mg} / \mathrm{dL}$ which gradually decreased to 95.1 and $91.4 \mathrm{mg} / \mathrm{dL}$ by consuming supplemented chapaties. At the initiation of the study, mean values of triglycerides was $165 \mathrm{mg} / \mathrm{dL}$ which gradually decreased to 143.6 and $138.4 \mathrm{mg} / \mathrm{dL}$ and mean values of glucose level were $83.16 \mathrm{mg} / \mathrm{dL}$, mean values of serum protein concentration were $6.5 \mathrm{~g} / \mathrm{dL}$ and mean values of albumin protein were $4.1 \mathrm{~g} / \mathrm{dL}$ which gradually increased to 4.2 and $4.5 \mathrm{~g} / \mathrm{dL}$ during 30 days trail. At the initiation of the study, the mean values of weight were $64.1 \mathrm{~kg}$ which gradually decreased to 63.2 and $62.4 \mathrm{~kg}$.

The individuals consuming chapaties made from wheat flour supplemented with $15 \%$ oat meal showed maximum cholesterol reduction ( $8 \%$ ) followed by $5.2 \%$ in consuming chapaties prepared from $15 \%$ barley flour supplemented in whole wheat flour whereas chapaties made from $7.5 \%$ oat and $7.5 \%$ barley flours induced $4 \%$ reduction as compared to control group (Fig. 1). It is obvious from the present findings that consumption of chapaties supplemented with barely flour and oat meal alone as well as in combination may be helpful in controlling serum cholesterol in hypercholesterolemic as well as in healthy individuals. In a study it was reported that reduction in cholesterol level after a meal containing oat meal are mainly due to the viscosity caused by $\beta$-glucan content of oat dietary fibre which decreases the concentration of bile acids in the body. Results of the present study was closely related to the findings of researchers which showed that by incorporation of barley and oat meal dietary fibre frequent reduction in the serum cholesterol concentration was occurred because dietary fibre bind with bile acids and decreased fat absorption in the body (El-Rabey et al., 2013; Hooda et al., 2009).

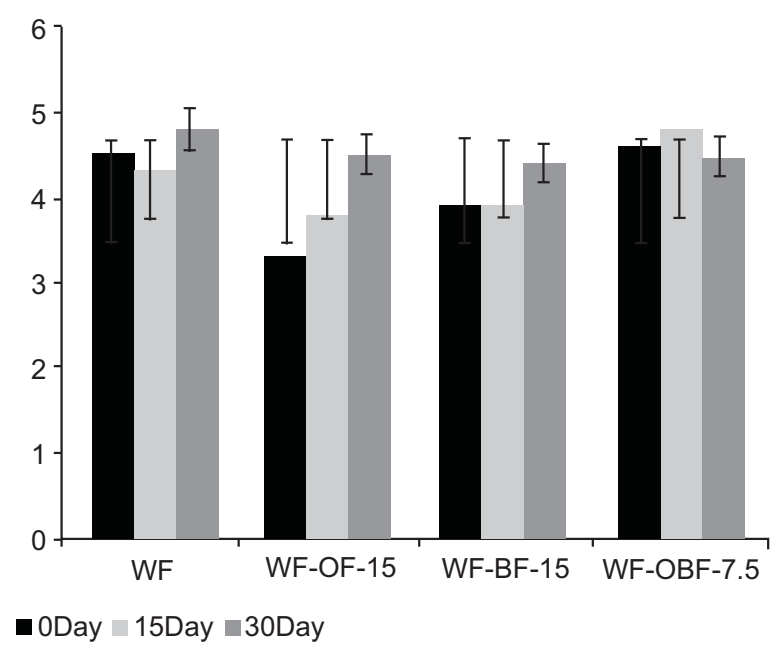

Fig. 1. Percent decrease in cholesterol. 
In a previous study it was explored that guar gum supplementation in the flour $(10 \%$ and $20 \%$ concentration) decreased blood total cholesterol significantly. The human volunteers consuming chapaties made from wheat flour supplemented with barley and oat meal showed little or no reduction in high density lipoprotein reduction as compared to control group (Tiwari and Cummins, 2011). The chapaties made from wheat flour supplemented with $15 \%$ oat meal showed maximum low density lipoprotein reduction (6.8\%) followed by $1.8 \%$ in $15 \%$ barley flour supplemented chapaties whereas chapaties made from $7.5 \%$ oat and $7.5 \%$ barley flours induced $1.5 \%$ reduction as compared to control group (Fig. 2-3). The healthy objects consuming chapaties

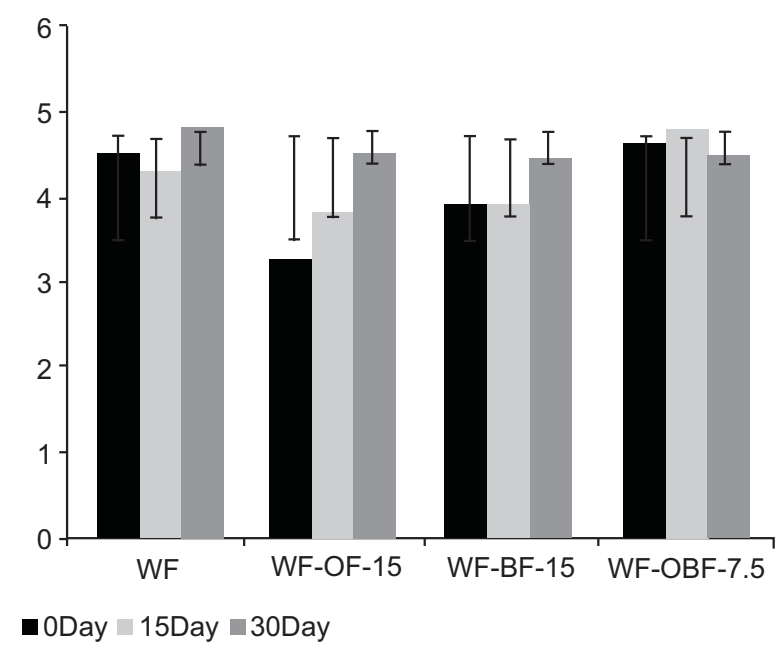

Fig. 2. Percent increase in HDL cholesterol.

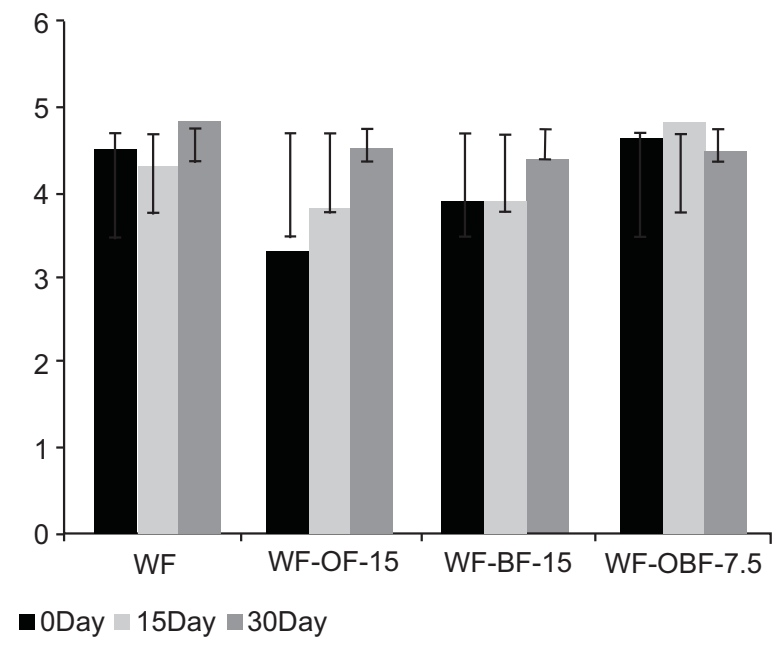

Fig. 3. Percent decrease in LDL cholesterol. made from wheat flour supplemented with $15 \%$ oat meal showed maximum triglycerides reduction $(28.5 \%)$ followed by $3.8 \%$ in consuming chapaties prepared from $15 \%$ barley flour supplemented in whole wheat flour whereas, chapaties made from $7.5 \%$ oat and $7.5 \%$ barley flours induced $2.5 \%$ reduction (Fig. 4). The consumption of such chapaties had slight effect on high density lipoprotein concentration in the healthy individuals. The consumption of dietary chapaties was helpful in controlling LDL level and blood triglycerides in heart patients. Results of the present study were closely related to earlier findings which showed $(16.33 \%)$ reduction in triglycerides level of rats fed on chapaties prepared from chick pea flour $5 \%+$ guar gum $1 \%,(12.31 \%)$ and (2.76\%) followed by guar gum $3 \%$ and $2 \%$, respectively as compared to control diet.

The chapaties made from wheat flour supplemented with $15 \%$ oat meal showed maximum glucose reduction $(5.5 \%)$ in persons followed by $3.5 \%$ in consuming chapaties prepared from $15 \%$ barley flour supplemented in whole wheat flour whilst chapaties made from 7.5\% oat and $7.5 \%$ barley flours caused $2 \%$ reduction as compared to wheat flour chapaties (Fig. 5). Dietary flour had significant effect on controlling blood glucose in hyperglycemic persons. Results of the present study were closely related to earlier findings which showed $(14.57 \%)$ reduction in glucose level of rats fed on chapaties prepared from chick pea flour $5 \%+$ guar gum $1 \%$, followed by $11.64 \%$ and $9.60 \%$ reduction due to guar gum $3 \%$ and $2 \%$, respectively as compared to control diet. Reduction in glucose and insulin responses

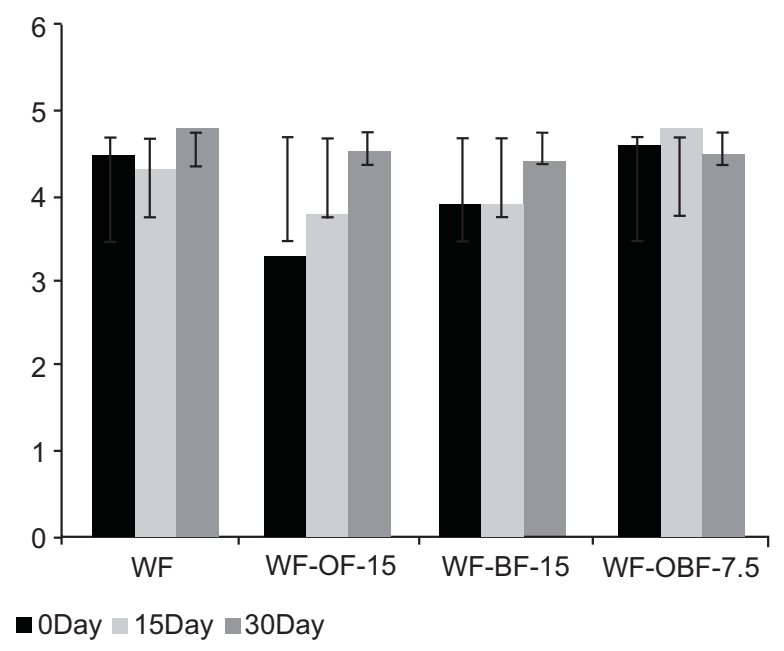

Fig. 4. Percent decrease in triglyceride. 
after a meal containing barley and oat meal are mainly due to the viscosity caused by $\beta$-glucan content of dietary fibre which accelerates the movement of food throughout the body.

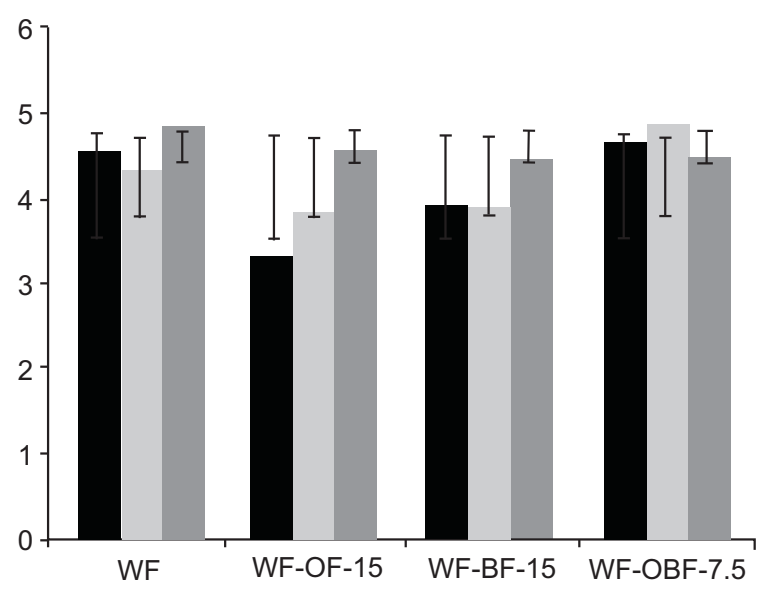

- 0Day $₫$ 15Day $₫$ 30Day

Fig. 5. Percent decrease in glucose.

The individuals consuming chapaties made from wheat flour supplemented with $15 \%$ oat meal showed maximum protein $(12.5 \%)$ and albumin protein concentration (15.7\%) followed by $11.1 \%$ and $12 \%$ in consuming chapaties prepared from $15 \%$ barley flour supplemented in whole wheat flour, respectively. Whereas, chapaties made from $7.5 \%$ oat meal and $7.5 \%$ barley flour induced $10 \%$ increase in protein and $11 \%$ in albumin protein concentration as compared to control group (Fig. 6-7).

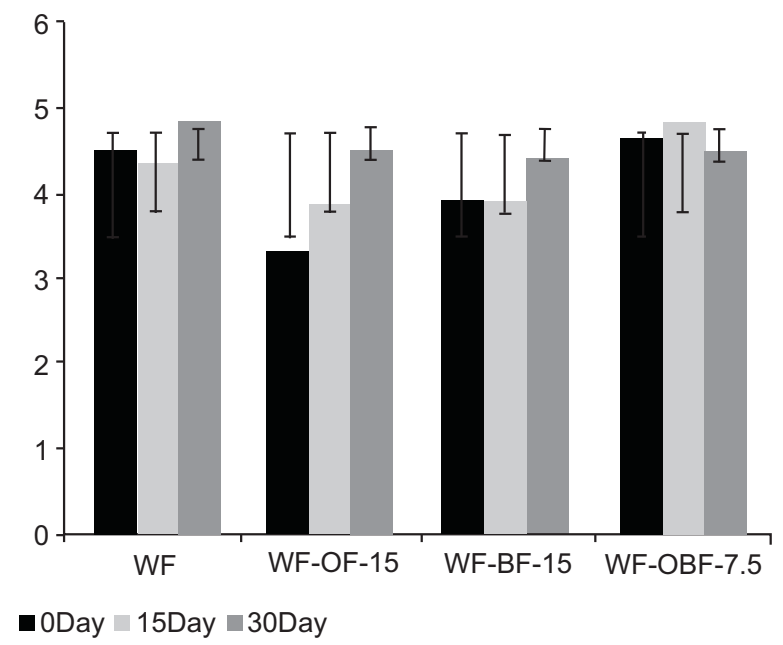

Fig. 6. Percent increase in serum protein.

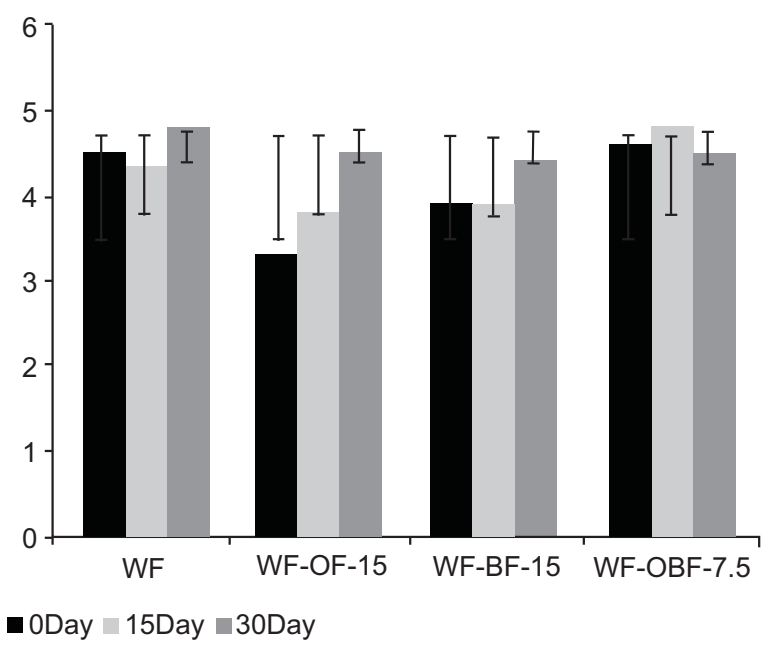

Fig. 7. Percent increase in albumin protein.

The chapaties supplemented with barely flour and oat meal increased the serum protein and albumin protein level of the individuals due to presence of high protein content. Results of this study were closely related to the findings of earlier scientists who reported that maximum serum protein $6.39 \mathrm{~g} / \mathrm{dL}$ and serum albumin protein $3.63 \mathrm{~g} / \mathrm{dL}$ were found in rats fed on chapaties prepared from blend of chickpea 5\% and guar gum 1\% flour as compared to control chapaties $(6.33 \mathrm{~g} / \mathrm{dL})$ and $(3.60 \mathrm{~g} / \mathrm{dL})$, respectively. The individuals consuming supplemented chapaties made from $15 \%$ oat meal showed maximum weight reduction $(4.7 \%)$ followed by $4.1 \%$ in consuming chapaties prepared from $15 \%$ barley flour whereas, chapaties made from $7.5 \%$ oat

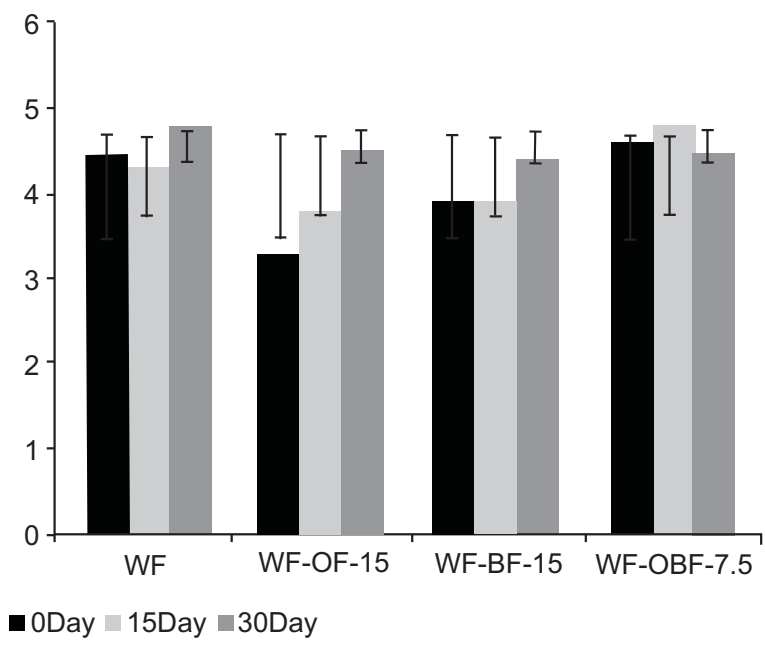

Fig. 8. Percent decrease in weight. 
meal and $7.5 \%$ barley flours prompted 3\% reduction as compared to control group (Fig. 8). The researchers reported that reduction in weight of normal and obese persons by consuming dietary fibre rich chapaties was mainly due to their effect of bulkiness but not given any caloric values.

\section{Conclusion}

From the present study it is concluded that oat and barley based chapaties should be made part of a regular diet in order to achieve health benefits associated with dietary fibre content. Composite flour technology must be encouraged for its nutritional and therapeutic effects on human heatlh. Dietary fibre rich chapaties prepared from selected compositions of barley and oat meal supplemented flours would be supportive for hypercholesterolemic and hyperglycemic individuals as well as normal humans.

\section{References}

AACC, 2000. The American Association of Cereal Chemists. Approved Methods of American Association of Cereal Chemists. American Association of Cereal Chemistry, Inc., St. Paul, Minnesota, USA.

Akhtar, S., Anjum, F.M., Rehman, S.U., Sheikh, M.A., Farzana, K. 2008. Effect of fortification on physicochemical and microbial stability of whole wheat flour. Food Chemistry, 110: 113-119.

Anjum, F.M., Ahmad, I., Butt, M.S., Sheikh, M.A., Pasha, I. 2005. Amino acid composition of spring wheats and losses of lysine during chapati baking. Journal of Food Composition and Analysis, 18: 523-532.

Butt, M.S., Shahzadi, N., Suleria, H.A.R., Sultan, T., Chohan, M.I. 2011. Effect of dietary fiber in lowering serum glucose and body weight in Sprague dawley rats. Functional Foods in Health and Disease, 8: 261-278.

Butt, M.S., Ahmad, A., Sharif, M.K. 2007. Influence of pectin and guar gum composite flour on plasma biochemical profile of streptozotocin induced diabetic male albino rats. International Journal of Food Properties, 10: 345-361.

El-Rabey, H.A., Al-Seeni, N.M., Hanan, M.A. 2013. Efficiency of barley bran and oat bran in ameliorating blood lipid profile and the adverse histological changes in hypercholesterolemic male rats.
Biomedical Research International, 2013: 1-10.

Haridas, R.P., Leelavathi, K., Shurpalekar, S.R. 1986. Test baking of chapatti development of a method. Cereal Chemistry, 63: 297-303.

Hemalatha, M.S., Rao, U.J.S.P., Leelavathi, K., Salimath, P.V. 2010. Influence of amylases and xylanase on chemical, sensory, amylograph properties and microstructure of chapati. Food Science and Technology, 43: 1394-1402.

Hooda, S., Matte, J.J., Vasanthan, T., Zijlstra, R.T. 2009. Dietary purified oat $\beta$-glucan reduces peak glucose absorption and portal insulin release in portal-vein catheterized grower pigs. Livestock Science, 134: 15-7.

Meilgaard, M.C., Civille, G.V., Carr, B.T. 2007. Sensory Evaluation Techniques, pp. 1-441, $4^{\text {th }}$ edition, CRC Press, New York, USA.

Sharif, K., Butt, M.S., Huma, N. 2005. Oil extraction from rice industrial waste and its effect on physicochemical characteristics of cookies. Nutrition and Food Science, 35: 416-427.

Sharma, P., Gujral, H.S., Singh, B. 2012. Antioxidant activity of barley as affected by extrusion cooking. Food Chemistry, 131: 1406-1413.

Slavin, J. 2004. Whole grains and human health. Nutrition Research Review, 17: 1-12.

Sramkova, Z., Gregova, E., Sturdik, E. 2009. Chemical composition and nutritional quality of wheat grain. Acta Chimica Slovaca, 2: 115-138.

Steel, R.G.D., Torrie, J.H., Dicky, D.A. 1997. Principles and Procedures of Statistics: A Biometrical Approach, 633 pp., McGraw Hill Book Co. Inc., New York, USA.

Sudha, M.L., Vetrimani, R., Leelavathi, K. 2007. Influence of fiber from different cereals on the rheological characteristics of wheat flour dough and on biscuit quality. Food Chemistry, 100: 13651370.

Thondre, P.S., Henry, C.J.K. 2009. High molecular weight barley $\beta$-glucan in chapaties (unleavened Indian flatbread) lowers glycemic index. Nutrition Research, 29: 480-486.

Tiwari, U., Cummins, E. 2011. Meta-analysis of the effect of $\beta$-glucan intake on blood cholesterol and glucose levels. Nutrition, 27: 1008-1016.

Wade, P. 1998. Biscuits, Cookies and Crackers. The Principle of the Craft.pp. 1-176, $1^{\text {st }}$ edition, Elsevier Applied Science, New York, USA. 